\title{
PENERAPAN MEDIA AUDIO VISUAL PADA MODEL PEMBELAJARAN STUDENT FACILITATOR AND EXPLAINING (SFAE) DALAM MENINGKATKAN HASIL BELAJAR IPS SISWA KELAS IV SDN KAMULAN II KECAMATAN TALUN KABUPATEN BLITAR
}

\author{
Novialita Angga Wiratama \\ Fakultas Keguruan Ilmu Pendidikan \\ Universitas PGRI Ronggolawe Tuban
}

\begin{abstract}
The purpose of this study is to describe the validity and reliability of science process skills based test instruments and the quality of science process skills based on test instruments is viewed from the level of difficulty, power difference, and deception in material objects and their properties for Grade $V$ SDN 010 Tarakan. The type of research used in this research is Formative Evaluation Research and Development design. Research Results there are 30 items in the form of multiple choice, the initial steps are validation by a team of experts in a very feasible category. The one to one trial was conducted in conjunction with the validation of the one-to-one trial experts to get $90 \%$ of students' responses in the very effective category. The results of the SPSS 21 program analysis show 20 questions in the valid category, the reliability is $r 11=0.585>r$ table $=0.284$. The results of the analysis of the AnatesV4 program show the level of difficulty with difficult categories of 1 item problem (3.3\%), the level of difficulty of the questions that are in the easy category a number of 1 items (3.3\%), the level of difficulty of the questions which are in the category of very easy number 2 items of questions (6.7\%), the level of difficulty of the questions in the moderate category, 26 items of questions (86.7\%), the results of the average power difference with a good criterion of 12 questions (40\%), and an effective deceiver as many as 28 items (93.3\%).
\end{abstract}

Keyword: Development of Test Instruments, Science Process Skills, Natural Sciences

\begin{abstract}
ABSTRAK
Tujuan penelitian ini untuk mendeskripsikan penerapan media audiovisual dengan menggunakan model SFAE dalam pembelajaran IPS siswa kelas IV SDN Kamulan II. Serta untuk mendeskripsikan hasil belajar siswa kelas IV dalam penerapan media audiovisual dengan menggunakan model SFAE dalam pembelajaran IPS siswa kelas IV SDN Kamulan II. Pendekatan yang digunakan dalam penelitian ini adalah pendekatan kualitatif. Sedangkan jenis penelitian yang digunakan adalah Penelitian Tindakan Kelas (PTK) Rancangan PTK yang digunakan pada penelitian ini menggunakan model Kemmis dan M.C Taggart. Hasil penelitian diperoleh data bahwa belajar siswa meningkat dari hasil nilai pada siklus I 40,4 sebesar siklus II 67,4 sebesar siklus III mengalami peningkatan menjadi 83,6. Ada 2 siswa yang belum mencapai ketuntasan belajar individu. Hal ini terbukti dari sikap keantusiasan siswa dalam memperhatikan media audiovisual. Siswa dapat menjawab pertanyaan yang diberikan guru secara cepat dan tepat. Mereka lebih termotivasi dan aktif berpartisipasi dalam kegiatan pembelajaran, misalnya aktif dalam merespon pertanyaan yang diajukan guru serta aktif dalam berdiskusi dan saling membantu teman pada saat diskusi. Ada 2 siswa yang belum mencapai ketuntasan belajar individu pada saat siklus III berakhir. Pelayanan terhadap 2 tersebut diantara guru selalu melakukan pendampingan pada saat pembelajaran dan selalu memberikan motivasi.
\end{abstract}

Kata Kunci: Pengembangan Instrumen Tes, Keterampilan Proses Sains, IPA

\section{PENDAHULUAN}

\footnotetext{
${ }^{1}$ Korespondensi : Novialita Angga Wiratama. PGSD Fakultas Keguruan Ilmu Pendidikan Universitas PGRI Ronggolawe Tuban. Email: Novialita3@gmail.com.
} 
Proses belajar mengajar merupakan inti dari proses pendidikan. Dalam proses belajar mengajar, guru menjadi pemeran utama dalam menciptakan situasi interaktif yang edukatif, yakni interaksi antara guru dengan siswa, siswa dengan siswa dan siswa dengan sumber belajar dalam menunjang tercapainya tujuan belajar. Usaha meningkatkan mutu pendidikan di Indonesia yang paling dominan adalah melalui proses belajar mengajar. Menurut Sadiman (1993:6) proses belajar mengajar pada hakikatnya adalah proses komunikasi. Proses komunikasi yaitu proses menyampaian pesan dari sumber pesan melalui saluran atau media tertentu kepada penerima pesan, pesan - pesan tersebut berupa isi ajaran dan didikan yang ada di kurikulum dituangkan oleh guru atau sumber lain kedalam simbul - simbul komunikasi visual maupun verbal.

Dalam proses pembelajaran hendaknya guru mampu mengoptimalan penggunaan media sebagai alat bantu penyampaian isi pembelajaran. Asra (2007: 5.5) mengemukakan bahwa kata media" secara harfiah berarti perantara atau pengantar, sedangkan kata pembelajaran diartikan sebagai suatu kondisi yang diciptakan untuk membuat seseorang melakukan sesuatu kegiatan belajar. Musfiqon (2012: 28) mengungkapkan bahwa secara lebih utuh media pembelajaran dapat digunakan sebagai perantara antara guru dan siswa dalam memahami materi pembelajaran agar lebih efektif dan efisien. Media pembelajaran merupakan wahana dan penyampaian informasi atau pesan pembelajaran pada siswa. Dengan adanya media pada proses belajar mengajar, diharapkan dapat membantu siswa dalam memahami isi pembelajaran yang disampaika oleh guru, sehingga meningkatkan hasil belajar dan prestasi belajar siswa.

Media dapat diartikan sebagai perantara atau penghubung antara dua pihak, yaitu antara sumber pesan dengan penerima pesan atau informasi audio adalah pendengaran, kegiatan mendengarkan (menyimak) secara aktual karena adanya stimulus auditif, selanjutnya otak meneruskan stimulus tersebut ke dalam urat syaraf otak dan memrosesnya, sehingga menghubungkan aspek kognitif yang sesuai dengan informasi baru ke peristiwa ingatan riil atau ke materi yang telah dipelajari sebelumnya. Asyhar (2011: 45) mendefinisikan bahwa media audio visual adalah jenis media yang digunakan dalam kegiatan pembelajaran dengan melibatkan pendengaran dan penglihatan sekaligus dalam satu proses atau kegiatan. Pesan dan informasi yang dapat disalurkan melalui 
media ini dapat berupa pesan verbal dan nonverbal yang mengandalkan baik penglihatan maupun pendengaran. Beberapa contoh media audio visual adalah film, video, program TV dan lain-lain. Langah penerapan media audio visual menurut Sumarno (2011) yaitu tahap persiapan media dan perangkat pembelajaran, Pelaksanaan dalam proses pembelajaran, Tindak lanjut diskusi, observasi, eksperimen, latihan.

Menurut Saidiharjo (dalam Mashudi, 2009:50) mengatakan bahwa IPS adalah hasil kombinasi atau hasil pemfusian atau perpaduan dari sejumlah mata pelajaran seperti geografi, ekonomi, sejarah, sosiologi, antropologi, politik. IPS mengkaji seperangkat peristiwa, fakta, konsep, dan generalisasi yang berkaitan dengan isu sosial. IPS adalah salah satu mata pelajaran yang mencakup beberapa disiplin ilmu guna untuk mempelajari kehidupan sosial yang bermanfaat bagi kehidupan sehari-hari. Manfaat yang akan diperoleh siswa setelah mempelajari IPS disamping mempersiapkan diri untuk berbaur dalam masyarakat, juga membentuk diri siswa sebagai anggota masyarakat yang baik dengan mentaati aturan yang berlaku dimasyarakat.

\begin{tabular}{llr}
\multicolumn{1}{c}{ Model } & pembelajaran & Student \\
Facilitator and & Explaining & (SFAE) \\
merupakan salah satu dari tipe & model \\
pembelajaran kooperatif. Di dalam kelas
\end{tabular}

kooperatif siswa belajar bersama dalam kelompok-kelompok kecil yang terdiri dari 4-6 orang siswa yang sederajat tetapi heterogen, kemampuan, jenis kelamin, suku/ras, dan satu sama lain saling membantu. Tujuan dibentuknya kelompok tersebut adalah untuk memberikan kesempatan kepada semua siswa untuk dapat terlibat secara aktif dalam proses berpikir dan kegiatan belajar mengajar (Trianto, 2007:41) SFAE merupakan suatu model yang memberikan kesempatan kepada siswa untuk mempresentasikan ide atau pendapat pada rekan peserta lainnya. Model SFAE adalah model pembelajaran yang digunakan oleh pendidik dengan maksud meminta siswa untuk berperan menjadi narasumber terhadap temannya di kelas. Widodo (2009) menuturkan model pembelajaran SFAE merupakan model pembelajaran dimana siswa/peserta didik belajar mempresentasikan ide/pendapat pada rekan peserta didik lainnya. Model pembelajaran ini efektif untuk melatih siswa berbicara untuk menyampaikan ide/gagasan atau pendapatnya sendiri. Model ini merupakan model yang mudah, guna memperoleh keaktifan kelas secara keseluruhan dan tanggungjawab secara individu. Dengan menerapkan model ini, siswa yang selama ini tidak mau terlibat akan ikut serta dalam pembelajaran secara aktif . Model 
pembelajaran SFAE melibatkan partisipasi siswa secara langsung sebagai fasilitator di depan kelas untuk memberikan penjelasan mengenai materi yang dibahas bersama. Model pembelajaran ini efektif untuk melatih siswa berbicara untuk menyampaikan ide/gagasan atau pendapatnya sendiri.

Langkah penerapan SFAE (dalam Suprijono, 2009:128-129) adalah (1) Guru menyampaikan kompetensi yang ingin dicapai; (2) Guru mendemonstrasikan/ menyajikan garis-garis besar materi pembelajaran; (3) Memberikan kesempatan siswa untuk menjelaskan kepada siswa lainnya misalnya melalui bagan/peta konsep. Hal ini bisa dilakukan secara bergiliran; (4) Guru menyimpulkan ide/pendapat dari siswa; (5) Guru menerangkan semua materi yang disajikan saat itu; (6) evaluasi; (7) penutup. Kelebihan model SFAE adalah keterlibatan siswa sangat besar dalam proses pembelajaran. Dalam proses pembelajaran siswa diharapkan untuk aktif dalam berdiskusi dan melakukan presentasi terhadap materi yang didapatkan. Kemampuan akademik siswa yang heterogen dimanfaatkan sebagai acuan untuk membentuk kelompok belajar kooperatif.

Hasil belajar merupakan hal yang dapat dipandang dari dua sisi yaitu sisi siswa dan dari sisi guru. Dari sisi siswa, hasil belajar merupakan tingkat perkembangan mental yang lebih baik bila dibandingkan pada saat sebelum belajar. Dari sisi guru, hasil belajar terlihat dari hasil yang diperoleh siswa, apabila siswa mendapatkan nilai yang maksimal maka hasil belajar dapat tercapai dengan baik. Menurut Kunandar (2013: 62) bahwa hasil belajar adalah kompetensi atau kemampuan tertentu baik kognitif, afektif, maupun psikomotorik yang dicapai atau dikuasai peserta didik setelah mengikuti proses belajar mengajar. Sedangkan menurut Susanto (2011: 277) bahwa hasil belajar yaitu perubahanperubahan yang terjadi pada diri siswa, baik yang menyangkut aspek kognitif, afektif , dan psikomotor sebagai hasil dari 20 kegiatan belajar. Secara sederhana, yang dimaksud dengan hasil belajar siswa kemampuan yang diperoleh anak setelah melalui kegiatan belajar. Berdasarkan uraian di atas dapat disimpulkan bahwa hasil belajar merupakan kemampuan belajar anak yang meliputi aspek kognitif, afektif, dan psikomotor. Selain itu hasil belajar merupakan suatu perubahan yang terjadi pada anak dalam proses belajar.

\section{METODE PENELITIAN}

Pendekatan yang digunakan dalam penelitian ini adalah pendekatan kualitatif. "Penelitian kualitatif adalah penelitian yang 
datanya berupa kata-kata atau pernyataanpernyataan (yang diperoleh memlalui wawancara, dokumen, peerdebreefing, angket terbuka, observasi, dll) dan data tersebut dianalisis secara kualitatif dengan tujuan untuk menemukan makna dibalik berbagai gejala/peristiwa yang tampak" (Akbar, 2009:13). Sedangkan jenis penelitian yang digunakan adalah Penelitian Tindakan Kelas (PTK). PTK adalah suatu penelitian tindakan (action research) yang dilakukan oleh guru yang sekaligus sebagai peneliti di kelasnya atau bersama-sama dengan orang lain (kolaborator) dengan jalan merancang, melaksanakan atau tindakan, mengobservasi dan merefleksikan tindakan secara kolaboratif dan parsitipatif yang bertujuan untuk memperbaiki atau meningkatkan mutu (kualitas) pembelajaran di kelas melalui suatu tindakan tertentu dalam suatu siklus (Kunandar, 2008:45).

Rancangan PTK yang digunakan pada penelitian ini menggunakan model Kemmis dan M.C Taggart (dalam Akbar, 2010:28). Siklus PTK dapat dilihat dalam Gambar 3.1 berikut ini.

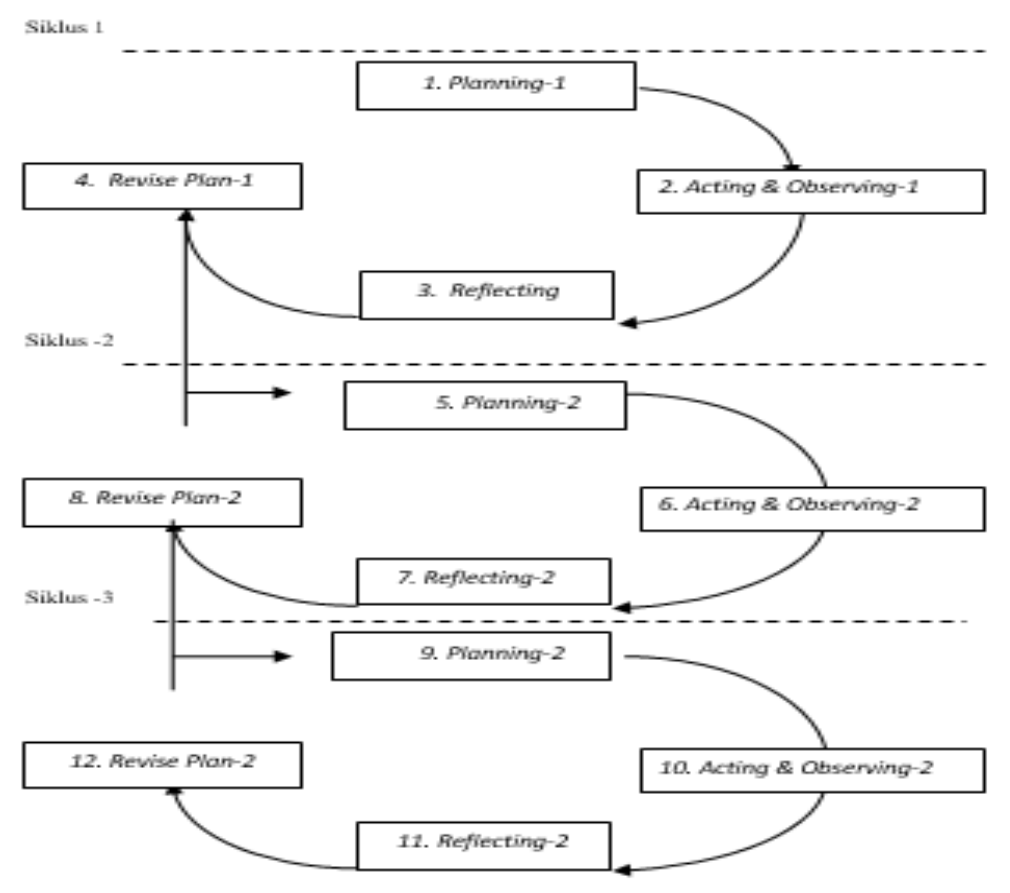

Gambar 3.1 Bagan Tahapan Siklus Model Kemmis \&Taggart (dalam Akbar, 2010:28)

Berdasarkan gambar struktur jalannya siklus PTK di atas, maka dapat ditarik kesimpulan bahwa rancangan PTK yang digunakan pada penelitian ini meliputi empat langkah, yaitu (1) merumuskan masalah dan merencanakan tindakan; (2) melaksanakan tindakan sesuai dengan rencana; (3) mengamati atau memonitor pelaksanaan tindakan; (4) merefleksi hasil pengamatan sebagai dasar untuk 
merencanakan tindakan selanjutnyadalam setiap siklus tindakan terdiri dari perencanaan (planning), tindakan dan observasi (acting \&observing), refleksi (reflecting) dan revisi/perbaikan perencanaan (reflecting).

Penelitian ini dilaksanakan di SDN Kamulan II pada siswa kelas IV pelajaran IPS . Peneliti bertindak sebagai pelaksana tindakan yang dibantu guru kelas IV sebagai observer. Subjek dalam penelitian ini adalah semua siswa kelas IV SDN Kamulan II tahun ajaran 2018/ 2019 pada semester genap dengan jumlah siswa 25 orang.

Pengumpulan data dilakukan dengan teknik observasi, tes, dokumentasi, dan catatan lapangan. Analisis data yang diperoleh harus diuji keabsahannya dengan menggunakan teknik triangulasi. Melalui teknik triangulasi dapat digunakan lebih dari satu teknik pengumpulan data yaitu teknik observasi, tes, catatan lapangan, dan dokumentasi. Sehingga data yang terkumpul lebih lengkap dan akurat, hal tersebut sesuai dengan pernyataan. Analisis diawali dengan mengumpulkan data melalui teknik observasi , tes, dokumentasi, dan catatan lapangan. Data yang telah terkumpul kemudian dipilih data sesuai dengan tujuan penelitian. Kemudian data ditulis secara runtut berdasarkan masing-masing instrumen pengumpulan data yang digunakan. Langkah selanjutnya yaitu memadukan data yang diperoleh dari beberapa instrumen pengumpulan data. Hasil pemaduan data tersebut dilakukan agar dapat memperoleh data yang valid dan terpercaya, yang kemudian data dianalisis dan disimpulkan.

\section{HASIL DAN PEMBAHASAN}

Berdasarkan penerapan pembelajaran IPS yang dilakukan oleh observer dalam hal ini yaitu guru kelas III. Diperoleh data-data sebagai berikut: 1) Pelaksanaan pembelajaran pada tahap pra tindakan dilaksanakan dengan mengacu pada buku paket dan LKS tanpa didahului penyusunan rencana pelaksanaan pembelajaran (RPP). 2) Metode yang digunakan adalah metode cermah sehingga guru memegang otoritas penuh dalam proses pembelajaran. 3) Siswa kurang menguasai materi pembelajaran. 4) Guru kurang menguasai materi pembelajaran. d) Guru kurang menggunakan media pembelajaran. Media yang digunakan oleh guru dalam menyampaikan materi hanya berupa media papan tulis serta media gambar yang ada pada buku paket. Hasil observasi dari nilai siswa yang terdapat dalam buku tugas milik siswa nilai siswa masih rendah. Sedikitnya terdapat 15 siswa mendapatkan cacatan merah dari guru. Dari paparan data di atas maka perlu diadakan perbaikan pembelajaran dengan 
menggunakan model pembelajaran yang dapat membawa siswa aktif dan terlibat secara langsung dalam proses pembelajaran.

\section{Tindakan Siklus I}

Dalam tahap perencanaan, peneliti melakukan persiapan, materi ajar, kondisi siswa, cara pembelajaran, dan media pembelajaran. RPP penggunaan media audiovisual dengan menggunakan model pembelajaran SFAE. Kompetensi Dasar dalam penelitian ini memahami manusia dalam dinamika interaksi dengan lingkungan alam, sosial, budaya, dan ekonomi Tahap pelaksanaan peneliti melakukan pembelajaran sesuai perencanaan. Pembelajaran meliputi kegiatan awal, inti dan akhir. Pada kegiatan awal peneliti bertindak sebagai guru melakukan apersepsi. Saat kegiatan inti, siswa dibagi menjadi 5 kelompok dengan masing-masing anggota 5 siswa. Kemudian guru memberikan LKS yang berisi tentang rangkaian gambar peristiwa sekitar Proklamasi. Selanjutnya siswa melakukan kegiatan sesuai dengan petunjuk LKS. Pada LKS terdapat kegiatan, yaitu mengamati rangkaian gambar peristiwa sekitar Proklamasi kemudian menceritakan sesuai gambar tersebut. Kegiatan akhir ditutup dengan egiatan refleksi dan tanya jawab.

Penilaian proses terdiri dari keaktifan, keberanian, kerjasama, ketepatan jawaban dan pengumpulan tugas siswa selama proses pembelajaran berlangsung. Penilaian proses menggunakan skala A (baik), B (cukup baik), dan C (kurang baik). Hasil observasi selama pembelajaran diperoleh data pada saat diskusi umum siswa masih banyak yang mengalami kesulitan dan membutuhkan bimbingan. Pada waktu melakukan diskusi, banyak siswa yang ramai. Ada yang ramai karena aktif ingin tahu banyak tentang materi yang sedang dipelajari. Namun tidak sedikit yang ramai karena tertarik bermainmain dan bercerita dengan temannya yang lain. Dari kegiatan tersebut juga ada beberapa siswa yang sering mengajukan pertanyaan, ada juga yang diam dan hanya mendengarkan. Ketika proses presentasi berlangsung siswa masih ragu dan kurang percaya diri. Guru menawarkan pada kelompok untuk melakukan presentasi namun tidak ada satupun kelpompok yang mau maju ke depan kelas. Salah satu siswa anggota kelompok penyaji presentasi menuliskan hasil diskusi di papan tulis supaya siswa lain bisa mencatat. Setelah hasil diskusi ditulis, siswa yang lain menanggapi hasil diskusi temannya. Kemudian guru menyimpulkan ide/pendapat dari siswa dan bersama siswa membahas materi yang telah dipelajari.

Dari hasil penilaian selama pembelajaran berlangsung, keaktifan siswa 
yang mendapat skala A (11 siswa), B (3 siswa), C (11 siswa). Keaktifan yang dinilai selama proses pembelajaran yaitu keaktifan siswa dalam menjawab pertanyaan guru. Keberanian, siswa yang mendapat A (10 siswa), B (4 siswa), dan C (11 siswa). Penilian keberanian siswa yaitu keberanian dalam menyampaikan pendapat. Kerjasama siswa yang mendapat A (8 siswa), B (7 siswa), C (10 siswa). Kerjasama yang dinilai selama proses pembelajaran yaitu kerjasama siswa selama proses pembelajaran dengan guru dan teman serta pada saat mengerjakan LKS. Ketepatan Jawaban siswa yang mendapat A (10 siswa), B (5 siswa), C (10 siswa). Ketepatan Jawaban dinilai selama proses pembelajaran yaitu ketepatan jawaban dalam menjelaskan kepada temannya. Penilaian hasil pada siklus I dilaksanakan melalui hasil tes tertulis yang merupakan hasil belajar siswa dengan KKM 70. Hasil belajar siswa mengerjakan soal tes tertulis berupa soal uraian 5 soal dan esai sebanyak 5 soal sehingga jumlah keseluruhan soal adalah 10 soal. Jumlah skor 1010, hasil rata-rata dari mengerjakan tes tertulis yaitu 40,4. Dari hasil tersebut siswa yang tuntas dalam belajar sebanyak 12 siswa sedangkan siswa yang tidak tuntas dalam belajar sebanyak 13 siswa.

Dari hasil refleksi siklus I didapatkan kesimpulan bahwa penerapan model pembelajaran SFAE belum dapat dilaksanakan secara maksimal karena siswa belum dapat belajar mandiri untuk memahami materi. Masih banyak siswa yang memerlukan bimbingan, sehingga guru masih banyak berperan dalam kegiatan pembelajaran. Hal ini diduga disebabkan karena apersepsi dan eksplorasi yang dilakukan guru masih belum optimal. Pengorganisasian kelas yang dilakukan guru masih belum berhasil. Pembentukan kelompok ditentukan oleh guru sehingga siswa tidak memperoleh kesempatan untuk membentuk sendiri. Hal ini mengakibatkan siswa yang tidak cocok dengan salah satu anggota kelompoknya tidak mau mengerjakan LKS. Sebagian besar siswa masih malas untuk memahami petunjuk langkah-langkah kegiatan yang ada di Lembar Kegiatan Kelompok, sehingga guru harus menerangkan berulang-ulang. Hal ini bisa dilihat dari ketidakseriusan siswa dalam membaca petunjuk. Misalnya, ketika ada salah satu siswa yang bertanya kemudian guru telah menjelaskan, tetapi masih ada saja siswa lain yang bertanya. Hasil belajar ratarata siswa yaitu 40,4 hal ini berarti belum mencapai Kriteria Ketuntasan Minimal dan masih ada 13 siswa yang belum mencapai Kriteria Ketuntasan Minimal. Hal ini berarti yang mencapai Kriteria Ketuntasan Minimal hanya 12 siswa, padahal seharusnya yang 
mencapai Kriteria Ketuntasan Minimal adalah $80 \%$ atau sejumlah 20 siswa. Dari hasil wawancara terhadap siswa, tingkat ketercapaian yang masih rendah karena soal yang sulit untuk dipahami. Berdasarkan data yang diperoleh pada siklus I peneliti melakukan tindakan siklus berikutnya.

\section{Tindakan Siklus II}

Tahap perencanaan pada siklus II diantaranya membuat RPP dengan model SFAE menggunaan media audiovisual, menyiapkan materi ajar dan media pembelajaran. Tahap pelaksanaan peneliti melakukan pembelajaran sesuai perencanaan. Pembelajaran meliputi kegiatan awal, inti dan akhir. Pada kegiatan awal guru melakukan apersepsi. Kegiatan inti, siswa dibagi menjadi beberapa kelompok. Siswa memilih sendiri anggota kelompoknya. Kegiatan akhir dalam pembelajaran ditutup dengan penarikan kesimpulan secara bersama, tanya-jawab dan refleksi. Hasil observasi selama proses pembelajaran, siswa sudah memahami perintah yang ada di LKS dan tidak banyak bertanya. Ketika menjawab soal pertanyaan siswa sangat antusias segera membaca buku mereka. Siswa berlomba-lomba untuk cepat dan tepat menyelesaikan soal-soal tersebut. Pengorganisasian anggota kelompok dengan penentuan dari guru diubah menjadi kelompok dengan pilihan siswa sendiri.
Penilaian proses kerjasama yang dinilai adalah tindakan kerjasama siswa terhadap kegiatan pembelajaran yang disajikan praktikan meliputi: (1) mau berusaha menemukan sendiri pengetahuannya, (2) mau mengerjakan tugas, dan (3) berani menyampaikan pendapat.

Hasil penilain tindakan siklus diperoleh data sebagai berikut. keaktifan siswa yang mendapat skala A (13 siswa), B (6 siswa), C (6 siswa). Keaktifan yang dinilai selama proses pembelajaran yaitu keaktifan siswa dalam menjawab pertanyaan guru aktif bertanya dengan pertanyaan kritis. Keberanian, siswa yang mendapat A (15 siswa), B (5 siswa), dan C (5 siswa). Selama siklus II berlangsung siswa sejumlah 10 orang tetap terlihat pasif. Hal ini terlihat pada siswa tidak mau menjawab pertanyaan guru, ketika ditunjuk guru untuk menjawab pertanyaan siswa hanya diam saja.Kerjasama siswa yang mendapat A (12 siswa), B (8 siswa), C (5 siswa). Ketepatan Jawaban siswa yang mendapat A (15 siswa), B (5siswa), C (5 siswa). Penilaian hasil berupa tes tertulis pada siklus II bahwa siswa kelas IV belum tuntas belajar. Jumlah skor tes tertulis 1685 dengan rata- rata kelas 67,4 dihitung dengan pembagian jumlah skor tertulis dengan jumlah siswa. Adapun hasil belajar dari siklus I dan siklus II bila dibandingkan akan terlihat peningkatan hasil 
belajar yaitu 27\%. Kriteria Ketuntasan Minimal, 17 siswa tuntas belajar. Berdasarkan hasil observasi pada siklus II dan hasil belajar siswa pada siklus yang mengalami peningkatan, praktikan menyimpulkan bahwa kegiatan pemecahan masalah pembelajaran pada kelas $\mathrm{V}$ mulai mengalami peningkatan. Berdasarkan data tersebut maka peneliti melakukan tindakan siklus III.

\section{Tindakan Siklus III}

Tahap perencanaan pada siklus III diantaranya membuat RPP dengan model SFAE menggunaan media audiovisual, menyiapkan materi ajar dan media pembelajaran. Tahap pelaksanaan peneliti melakukan pembelajaran sesuai perencanaan. Pembelajaran meliputi kegiatan awal, inti dan akhir. Pada kegiatan awal guru melakukan apersepsi. Kegiatan inti, siswa dibagi menjadi beberapa kelompok. Kegiatan akhir dalam pembelajaran ditutup dengan penarikan kesimpulan secara bersama, tanya-jawab dan refleksi. Hasil observasi selama proses pembelajaran, siswa sudah memahami perintah yang ada di LKS. Ketika menjawab soal pertanyaan siswa sangat antusias segera membaca buku mereka. Siswa berlombalomba untuk cepat dan tepat menyelesaikan soal-soal tersebut. Penilaian proses kerjasama yang dinilai adalah tindakan kerjasama siswa terhadap kegiatan pembelajaran yang disajikan praktikan meliputi: (1) mau berusaha menemukan sendiri pengetahuannya, (2) mau mengerjakan tugas, dan (3) berani menyampaikan pendapat. Keberanian, siswa yang mendapat A (20 siswa), B (3 siswa), dan C (2 siswa). Kerjasama siswa yang mendapat A (20 siswa), B (4 siswa), C (1 siswa). Ketepatan Jawaban siswa yang mendapat A (20 siswa), B (3 siswa), C (2 siswa). Penilaian hasil yaitu berupa tes tertulis pada siklus III adalah siswa kelas IV tuntas belajar. Jumlah skor tes tertulis 2090 dengan rata- rata kelas 83,6 dihitung dengan pembagian jumlah skor tertulis dengan jumlah siswa. Adapun hasil belajar dari siklus I hingga siklus III bila dibandingkan akan terlihat peningkatan hasil belajar. Berdasarkan hasil observasi pada siklus III dan hasil belajar siswa pada siklus yang mengalami peningkatan, praktikan menyimpulkan bahwa kegiatan pemecahan masalah pembelajaran pada kelas IV telah berhasil mencapai tujuannya. Yaitu metode pembelajaran yang bervariasi, pemanfaatan media pembelajaran yang mampu menarik perhatian dan motovasi siswa untuk melakukan kegiatan pembelajaran, pertahanan konsentrasi siswa terhadap pembelajaran dan peningkatan hasil belajar.

\section{PENUTUP}




\section{Simpulan}

Berdasarkan hasil penelitian, maka dapat disimpulkan bahwa penggunaan media audiovisual pada model pembelajaran Student Facilitator And Explaining mata pelajaran IPS Kompetensi dasar memahami manusia dalam dinamika interaksi dengan lingkungan alam, sosial, budaya, dan ekonomi, mampu meningkatkan aktifitas siswa dalam belajar. Hal ini terbukti dari sikap keantusiasan siswa dalam memperhatikan media audiovisual. Siswa dapat menjawab pertanyaan yang diberikan guru secara cepat dan tepat. Mereka lebih termotivasi dan aktif berpartisipasi dalam kegiatan pembelajaran, misalnya aktif dalam merespon pertanyaan yang diajukan guru serta aktif dalam berdiskusi dan saling membantu teman pada saat diskusi. Hasil belajar siswa juga meningkat dari hasil nilai pada siklus I 40,4 sebesar siklus II 67,4 sebesar siklus III mengalami peningkatan menjadi 83,6. Ada 2 siswa yang belum mencapai ketuntasan belajar individu pada saat siklus III berakhir.

\section{DAFTAR PUSTAKA}

Akbar, Sa'adun. 2009. Penelitian Tindakan Kelas: Filosofi, Metodologi, Implementasi. Yogyakarta: Cipta Media Aksara.

Akbar, S. 2010. Penelitian Tindakan Kelas Filosofi, Metodologi, dan Implementasinya. Yogyakarta: Cipta Media Aksara.

Asra, Darmawan dan Riana (2007). Komputer dan Media Pembelajaran di SD. Dirjendikti : Jakarta.

Asyhar, Rayanda. 2011. Kreatif Mengembangkan Media Pembelajaran. Gaung Persada (GP) Press Jakarta. Jakarta

Kunandar. 2008. Langkah Mudah Penelitian Tindakan Kelas Untuk Meningkatkan Kinerja Guru dan Dosen. Jakarta: Remaja Rosdakarya.

Kunandar. 2008. Langkah Mudah Penelitian Tindakan Kelas Sebagai Pengembangan Profesi Guru. Jakarta: PT Raja Grafindo Persada

Mashudi, Toha. 2009. Bahan Ajar Strategi Belajar Mengajar IPS di Sekolah Dasar. Malang : Universitas Negeri Malang.

Musfiqon. 2012. Pengembangan Media dan Sumber Pembelajaran. Jakarta: Prestasi Pustaka. Moleong, J Lexy. 2007. Metodologi Penelitian Kualitatif. Bandung. Remaja Rosdakarya. Sardiman. 1994. Interaksi dan Motivasi Belajar Mengajar. Jakarta: Raja Grafindo Persada. 
Sumarno, Ali. Kreativitas Belajar.

(http://elearning.unesco.ac.id/mybog/alimsumarno/kreativitas-belajar) diakses hari Rabu, 1 Januari 219 Pukul 16.00 WIB.

Susanto, Ahmad. 2013. Teori Belajar \& Pembelajaran di Sekolah Dasar. Jakarta: Kencana.

Suprijono, Agus. 2009. Cooperative Learning: Teori dan Aplikasi Konsep. Yogjakarta: Pustaka Belajar

Trianto.(2007). Model-model Pembelajaran Inovatif Berorientasi Konstuktivistik. Jakarta: Prestasi Pustaka. 